\title{
Inside the transnational social space: Cross-border management and owner relationship in a German subsidiary in Hungary ${ }^{*}$
}

\section{Christoph Dörrenbächer**}

This paper examines the social relationships in and around a German subsidiary in Hungary during the first 15 years of Hungarian transition to a market economy. It draws on a recent conceptual framework that sees multinational corporations as transnational social spaces, in which transnational communities - communities of individuals that exhibit a unique cross-national organisational identity - may emerge. Empirically investigating two basic types of cross-border social relationship in multinational corporations, the paper argues that, due to the constant interplay of crossborder management and ownership relationships, the emergence of transnational communities is a demanding process, with established communities being precarious entities.

Aufbauend auf ein aktuelles Konzept, das multinationale Unternehmen als transnationale soziale Räume begreift, beschäftigt sich dieser Beitrag mit den grenzüberschreitenden Sozialbeziehungen einer deutschen Tochtergesellschaft in Ungarn. Im Detail untersucht der Beitrag wie sich die Management- und Eigentümerbeziehungen in der genannten Tochtergesellschaft über die ersten 15 Jahre des Transformationsprozesses hinweg entwickelt haben. Hauptargument ist dabei, dass grenzüberschreitende Sozialbeziehungen in multinationalen Unternehmen aufgrund des Wechselspiels von Management- und Eigentümerbeziehungen nur selten die Form transnationaler Gemeinschaften (Gemeinschaften, die eine besondere grenzüberschreitende organisationale Identität ausbilden) annehmen.

Key words: Multinational corporations, Transnational social space, Transnational communities, Headquarters-subsidiary relationships, Knowledge transfer

* Manuscript received: 20.06.06, accepted: 10.07.07 (1 revision)

** Christoph Dörrenbächer, Dr./Ass. Prof, University of Groningen. Main research areas: Multinational corporations, international human resource management, career development, knowledge transfer and subsidiary role development. Corresponding address: c.dorrenbacher@rug.nl. 


\section{Introduction}

Multinational corporations (MNCs) are some of the most complex and hence most intriguing organisations in the modern world. Their organisational differentiation and geographical spread contribute to their complexity; in fact, some corporations operate in the majority of the world's countries. Moreover, assessment of MNCs and their activities differ greatly. While some consider MNCs to be "a powerful force for the good" (The Economist 2000:19), others hold a more critical view of corporations that span nation states, economic systems, cultures, and religions. This controversy, along with a colourful history of centuries of cross-border business activity undertaken by MNCs and their antecedents, i.e. medieval trade guilds, colonial trading companies and early joint stock companies, have ensured that multinational corporations attract considerable academic interest. The last fifty years, in particular, have seen a surge in attempts to explain the nature und behaviour of multinational corporations, international production, and cross-border management. To date most approaches employ distinctly economic and management perspectives, contributing to the rapidly growing field of international business (IB) literature. In contrast, organisation studies have played a minor but growing role in explaining the cross-border business activities of MNCs.

Early organisation studies of MNCs, undertaken in the 1970s, were limited to looking at how organisational structure is a function of corporate strategy and environmental contingencies. Subsequent studies in the 1980s examined the process by which MNCs are simultaneously shaped by different contextual influences, e.g. home and host country institutional influences or combined organisational and institutional influences. Both streams of research were deeply rooted in a structuralist tradition. Only very recently has this tradition begun to lose sway to a more open structural analysis and action perspective that conceptualises MNCs as transnational social spaces.

The notion of transnational social spaces is an offshoot of labour migration studies, ethnic studies, world society theories and the literature on economic globalisation. The concept suggests that MNCs are arenas in which socioeconomic action takes place, multiple social relationships emerge, sense is made, power is exercised and the dynamics of consensus, conflict and resistance are played out (Geppert/Clark 2003; Morgan 2001a, b; Pries 2001). The transnational social space approach can be clearly distinguished from the other approaches mentioned by the fact that it, firstly, deconstructs social reality in MNCs into a more open-ended set of cross-border social relationships and, secondly, suggests that cross-border social relationships may take the form of transnational communities. It draws attention to social relationships that exhibit a unique cross-national organisational identity and that cannot be reduced simply to the interplay of national influences and interests (Morgan 2001a). 
To date, the concept of transnational social space has been used in a rather vague fashion, and different dimensions of the transnational social space have been simply conflated. Analytical differentiation between different types of relationship in this transnational space and empirical investigation of such social relationships is required. Which social relationships co-exist in the setting of one specific MNC? What form do these relationships take and how do they interact with one another?

The purpose of this paper is to propose initial answers to these questions. Based on a longitudinal in-depth case study of Siemens-Telefongyár, a GermanHungarian venture in the telecommunications equipment industry, this paper empirically illustrates that multiple processes of boundary-crossing are inherent to all MNC activities abroad. The study shows that cross-border management relationships and owner relationships are two essential types of social relationship in an MNC. By more closely examining these two types of relationship over the 15 years of transition from a communist to a market economy, the case study demonstrates that social relationships in MNCs develop unevenly and that the emergence of transnational communities in MNCs is a demanding process. Moreover, the case study shows that transnational communities are precarious entities, because the underlying cross-national organisational identity is constantly threatened by other social relationships in and around the $\mathrm{MNC}$, as well as by changes in the business environment.

The first section of the paper provides a short conceptual discussion of MNCs as transnational social spaces based on gaps identified in existing intraorganisational research on MNCs. Moreover, this section analytically specifies relevant types of social relationship and defines the characteristics they exhibit. The following section explains the methodology. The case study is introduced in the subsequent section and the transnational social space of an MNC is investigated by exploring different cross-border management and owner relationships. The management relationships elucidated in greater empirical detail comprise the different relationships of Siemens expatriates and their Hungarian counterparts at top and the middle management levels.

Conceptually these relationships touch upon the strategic and operational dimension of the transition process at Siemens-Telefongyár. The owner relationships explored here include both intra-organisational owner relationships as well as the overall owner-management relationships at Siemens. These relationships represent the different layers of governance to which the venture was and is subject. The paper closes with a short discussion of the quality and interrelatedness of these two types of cross-border social relationship, as well as with the theoretical implications of the case study. 


\section{Multinationals as transnational social spaces}

For a rather long time organisation studies (and the IB literature) treated MNCs as hierarchical entities in which power resided entirely in headquarters and with managers from headquarters. It was not until research turned to corporations from different home countries that this picture changed. Thus, research carried out by Stopford and Wells (1972) on US multinationals and Franko (1976) on European multinationals showed that European MNCs were much more decentralised then their counterparts with headquarters in the United States. One of the first authors to translate these empirical findings into a more theoretical concept was Gunnar Hedlund. In his famous 1986 article "The hypermodern MNC - A heterarchy?", Hedlund observed that heterarchical MNCs - unlike hierarchical ones - have many centres, and that subsidiaries of this type of MNC are given a strategic role, not only for their own subsidiary but for the multinational as a whole (Hedlund 1986). Similar concepts followed, such as the MNC as an "integrated network" (Bartlett/Ghoshal 1989), or the MNC as a "transnationally differentiated network", a term coined by Nohria and Ghoshal (1997) approximately a decade later. In all of these concepts, the role of the headquarters was relativised and power structures within the multinational were seen as diverse, context-related and relationship-based.

This new paradigm also inspired the more narrow discussion on headquarterssubsidiary relationships in MNCs. Here, extant research was basically concerned with the decentralisation of decision-making authority in MNCs and issues of coordination and control, with both aspects considered as intrinsically interrelated. Decentralisation of decision-making authority by MNC headquarters in favour of their subsidiaries was seen as influenced by a number of factors, including industry type, country of origin, type of value-chain activity and overall organisational complexity (Gates/Egelhoff 1986). Subsidiary-related factors such as subsidiary size and capabilities or advantages tied to the location of the subsidiary were considered much less important (van den Bulcke 1984; Baliga/Jaeger 1984). Despite these studies, which played down the role of subsidiaries, the overall paradigmatic change towards more heterarchic structures within MNCs shifted research attention towards the specific role and contribution of subsidiaries (cf. Birkenshaw 2001; Johnston 2005). Common to these contributions is their assumption that subsidiaries are more then just executive organs of headquarters but potentially important organisational units that produce firm-specific advantages (Taggart 1998).

Moreover, as Birkenshaw (1996; 2000) has pointed out most prominently, subsidiaries follow their own strategies, which do not necessarily accord with the intentions of headquarters, leading to subsidiary initiative and entrepreneurship both within and outside the MNC. Thus, depending on their autonomy and power position (Forsgren et al. 2005), subsidiaries struggle to enlarge their mandate, to enhance their role or to autonomously follow business 
opportunities in their local environment (White/Poynter 1984; Birkenshaw 2000; Kristensen/Zeitlin 2005).

While the growing emphasis on subsidiaries as partly autonomous actors with their own agendas has opened up a perspective that allows a better understanding of power, politics and conflicts in headquarters-subsidiary relationships (cf. Dörrenbächer/Geppert 2006), the literature to date still displays some shortcomings that need to be addressed by a less restrictive approach. Thus, rather little is known about key actors, their rationales and interactions in headquarters-subsidiary relationships. What kinds of managers organise headquarters-subsidiary relationships? What rationales can be assigned to them? What strategies do they follow and what kinds of social relationships emerge between headquarters and subsidiary managers? Answers to these questions are still very piecemeal and sometimes subject to rather broad assumptions. For instance, actor rationales in headquarters-subsidiary relationships are assumed to follow either general behavioural patterns such as risk avoidance (Aharoni 1966) or a 'not invented here' attitude (Edwards et al. 1999), or to be strongly shaped by the (sub-)organisational origins of actors (Birkenshaw/Ridderstråle 1999). This clearly neglects other important rationalities such as functional and hierarchical background, national origins or career orientation.

Addressing these open questions, some authors have recently proposed conceptualising MNCs as transnational social spaces (Geppert/Clark 2003; Morgan 2001a, b; Pries 2001). Two core features are encapsulated by the notion of the MNC as a transnational social space. First, conceptualising MNCs as transnational social spaces places a strong emphasis on cross-border social relationships that emerge within MNCs through continued and structured interaction between actors that belong to different organisational units. Thus, MNCs are basically understood as pluri-local entities formed by multiple and complex social relationships. This moves beyond the dominant paradigm, which claims to map the social order in an MNC by concentrating on headquarters' strategies or on headquarters-subsidiary relationships, and makes abandoning the unrealistic notion of MNCs as unified rational actors possible (Morgan 2001a:11). Second, these multiple and complex cross-border social relationships are not seen as characterised by a single factor but by the interplay of multi-sited social realities (or "site ontologies" as coined by Schatzki 2005:471) composed of material arrangements, social practices, institutional frames and interpretative schemes of key actors (Pries 2001:28 Clark et al. 2001:5; Geppert/Clark 2003:436). Material arrangements refer to set-ups of human-made things (e.g. machines, buildings), artefacts (technologies, software) and other human beings (workforces). Social practices are defined as organised, open-ended spatialtemporal actions that are both structured by and restructure material arrangements (Pries 2001:22; Schatzki 2005:471). In the case of an MNC this includes practices on the level of the subsidiary (e.g. the management of the 
labour force), as well as practices on the overall MNC level (e.g. reporting, monitoring and benchmarking systems). Institutional frames refer to the impact of the wider socio-political home and host country context both on material arrangements and social practices. Actors' interpretative schemes stress the importance of actors' meanings and sense-making as logic for specific action (Weick 1995).

Depending on the interplay of these factors, it is argued that social relationships in MNCs can take different shapes. Explicitly included here is the emergence of so-called transnational communities, i.e. communities of individuals in MNCs that exhibit a unique cross-national organisational identity, despite the fact that their national and organisational roots vary. The emergence of transnational communities is understood as a result of "the interplay between top-down projects of transnationalism, pursued by powerful actors, and bottom-up processes of mutual identification and collective awareness" (Morgan 2001b:118).

Another important difference relates to the basic rationale of social relationships in MNCs. Following findings from research on international joint ventures (Inkpen/Beamish 1997; Shenkar/Yan 2002), social relationships in MNCs can be grouped analytically into either management or governance relationships. Governance relationships enable the discussion, definition, and modification of the constitutional rules and mandates in an $\mathrm{MNC}$, while management relationships focus on how these constitutional rules and mandates are interpreted and applied operationally and strategically. These two generic types of cross-border social relationship in MNCs strongly influence each other.

Finally, social relationships in MNCs are constructed by different groups of individuals. Focusing on cross-border management issues, different kinds of headquarters and subsidiary managers are involved. Here, extant research has stressed that there are large differences between top and middle managers (Stewart 1976; Petit 1981). This does not only apply to tasks and functions, but also to behavioural patterns. Ganter and Walgenbach (2002:167) for instance consider middle managers as much more open to cultural influence, while Huy (2001:73) stresses that middle managers leverage informal networks to make organisational change possible far more successfully than top managers. Strong attitudinal differences were also reported with regard to different kinds of foreign subsidiary managers.

Following a well-established categorisation, foreign subsidiary managers are either expatriates (parent-country nationals and third-country nationals) or inpatriates, i.e. local host country nationals (Harzing 1999). These different types of staff are understood to have different orientations. Usually expatriates are seen as strongly following a headquarters orientation due to their familiarity with the MNC's overall goals, policies and practices. They are frequently seen as most efficient in exercising headquarters control over the subsidiary. Local 
managers or inpatriates, on the other hand, are seen as having a generally local orientation, due to their socialisation in the host country and their familiarity with the social, political and economic environment of the host country (Harvey et al. 1999).

Based on this conceptual framework, the following case study examines the transnational social space of an MNC by investigating cross-border management and governance relationships. The case study deals with issues of cross-border knowledge transfer and processes of subsidiary role development; topics well suited to research into the nature of social orders in MNCs (Morgan 2001a:12).

\section{Methodology}

Given the scarcity of empirical knowledge on the multiplicity of cross-border social relationships and on the complex and fragmented nature of social order in MNCs, a single case study was used to provide insight into these subjects. The case study was designed to be both descriptive and explanatory using multiple within-case comparisons (Yin 2003; Eisenhardt 1989). The case study focused on the following questions: What kind of cross-border social relationships exist in MNCs? How and why do their characteristics differ? What overall picture of the social order in an MNC emerges from this empirical evidence?

The data were collected in 26 interviews carried out between 1999 and 2004 at different Siemens units in Germany, Austria and Hungary, both at the headquarters and the subsidiary level. The semi-structured interviews based on an interview guideline usually lasted an hour and a half. A few of the interviews were group interviews; some people were interviewed several times. All interviews except one were taped and transcribed. Interview sections that touched upon social relationships were coded and processed with the help of text-related information management software.

The interviews centred on the strategic and operational dimension of the transition process at Siemens-Telefongyár, with a focus on issues of knowledge transfer and subsidiary-role development. The topics addressed in the interviews were somewhat standardised. However some variations in questions occurred due to the different organisational, functional and hierarchical background of the interviewees. Given the fact that transformation in former socialist Central and Eastern European countries has taken place over a rather long period of time (Balaton 2004), the interviews aimed to map 15 years (1989 - c2004).

Access to interview partners was initially facilitated by a sponsor in the headquarters' top management. After conducting a few interviews, we decided to also use the snowballing approach (Welch et al. 2002), asking our interview partners to name and, in turn, recommend us to their counterparts in social relationships. This was mainly due to the fact that being backed by a top manager from the headquarters led to suspicions about our motives in 
conducting the research, resulting in monosyllabic and/or seemingly calculating answers by some interview partners. In line with the general findings of Soulsby (2004) and Michailova (2004) on problems of qualitative fieldwork in Central and Eastern Europe, this behaviour was clearly more pronounced among our Hungarian than among our German or Austrian interview partners. Using the snowballing approach not only helped us to build trust and openness among the Hungarian interviewees, it also ensured that we could interview at least one partner from each side of a social relationship in order to gain a multi-faceted view on social relationships in MNCs.

Interviews at the German headquarters and with German or Austrian expatriates in Hungary were conducted in German. Interviews with Hungarian managers and Hungarian stakeholders were conducted in Hungarian with the help of a Hungarian colleague who simultaneously interpreted. Similar to the experiences reported by Steger (2004) and Balaton (2004), in-depth discussions with this colleague on the interviews not only helped in avoiding (minimising) misunderstandings but also enabled a much better understanding of the motivation and the behaviour of the Hungarian interview partners. The discussions were also a great help in the subsequent process of data analysis. Commentary field notes on the specific conditions, main events, immediate impressions and ideas that arose during interviews were recorded immediately after the interview and frequently consulted during the later process of data analysis.

The statements in the interviews were corroborated in other interviews and with document data. Document data that were integrated into a 'company development profile' were taken from a multitude of sources (from the company itself, from newspapers and journals, from company handbooks and other company-related databases, from national and international chambers of commerce, as well as from investment-promotion agencies). Further steps to improve the validity and reliability of the research included feedback meetings with interview partners on interim results, as well as a triangulation of the overall case by a second investigator (Houman-Anderson/Skaates 2004), i.e. the Hungarian colleague who interpreted during the interviews.

\section{Social relationships in and around the Siemens-Telefongyár venture}

To understand the dynamics of the cross-border management relationships during the period under study, the strategic background of the SiemensTelefongyár venture is presented, as well as a brief history of this venture covering the years from 1989 to 2004 . We then move to the description of crossborder management relationships, addressing the transition process itself. Next, owner relationships are explored, first at the intra-organisational headquarterssubsidiary level and then at the overall level of the MNC. 


\section{Background and history}

The acquisition of the Hungarian telecommunication equipment supplier Telefongyár was one of the many acquisitions that Siemens undertook in Central and Eastern Europe immediately after the fall of the Berlin Wall. At that time, the low volume of the Central and Eastern European market for electronic products and services compared to the Western European market suggested a tremendous potential for growth, with Siemens expecting particularly high profits in infrastructure businesses such as telecommunications, energy and transportation. Additional reasons for building up major manufacturing facilities in Central and Eastern Europe included low wages and a skilled workforce in close geographic proximity to the home country (Mirow 1996). With the exception of the Czech Republic, which became the major export platform of Siemens in Central and Eastern Europe, Siemens' investments in Central and Eastern European countries generally aimed at market access. A strong correlation between local production and local market share emerged in these countries, with local production aiming at securing the market position of Siemens. This was also the case with Hungary and in particular with the Siemens-Telefongyár venture.

Prior to the fall of the Wall, the Budapest-based Telefongyár was one of the three leading telecommunication equipment suppliers in Hungary that concentrated on the development and production of transmission equipment. Since Hungary was a major supplier of telecommunications equipment in the Council for Mutual Economic Assistance (CMEA) (Müller 1998), a notable part of Telefongyár's production was exported. Russia alone accounted for about three-quarters of production in 1988 (Neumann et al. 1993). Additional exports went to other CMEA countries, as well as to some Arab countries.

It is unclear as to whether there had already been contacts between Telefongyár and Siemens regarding the most important pre-transition telecom project of Siemens in Hungary - i.e. the delivery of switching equipment for the Hungarian data network in the 1980s. However, from at least June 1989, Siemens and Telefongyár held close discussions about a cooperation agreement regarding public switching technology (Das Parlament 1990). These discussions led to a joint Siemens-Telefongyár bid in the 1990 tender by the main Hungarian Telecom operator MATAV for switching technology. With the success of the Siemens-Telefongyár bid announced by MATAV at the end of 1990, discussions about the acquisition of Telefongyár by Siemens gained further momentum. This was especially due to the formal obligation in the tender that the contractor had to maintain a local production unit in Hungary to serve the contract. This obligation was restated in the 1995 follow-up tender, imposing a requirement for local production on Siemens until 2001.

Managers were assigned from Siemens Austria to manage the acquisition and modernisation of Telefongyár. They began work at Telefongyár in spring 1991, 
even though the formal acquisition was not finalized until September 1991. This interim phase was characterised by ongoing conflicts between Siemens and ÀPV, the Hungarian privatisation agency regarding the conditions of the acquisition (including the price of Telefongyár). A few important changes were prepared or implemented in this phase, such as the dismantling of some operations, the screening of the stock of orders, as well as an assessment of the top management of Telefongyár. Once the formal acquisition took place, $65 \%$ of the shares of Telefongyár were taken over by the Austrian regional company (Siemens Austria). According to official statements this was mainly due to the tax breaks offered by the Austrian government for foreign direct investments. The remaining $35 \%$ were adopted by the Hungarian regional company Siemens $\mathrm{Kft}$, a $100 \%$ subsidiary of Siemens AG Germany. However in the mid-1990s Siemens AG Germany adopted the shares of Siemens Austria in Telefongyár.

A complete reorganisation of Telefongyár began more or less immediately after the formal acquisition. It was based on the assessments conducted in the pretakeover phase and affected all functional areas and hierarchical levels. Under the guidance of the Austrian expatriates, the initial years were used to downsize the company, refocus production, train middle management and implement Siemens standards throughout Telefongyár. By the mid-1990s the transition process at Telefongyár was more or less concluded. A period of positive business development and high dividends followed. For approximately five years the profitability of Telefongyár clearly exceeded that of other Siemens' subsidiaries in Hungary, as well as those of Siemens switching subsidiaries elsewhere in Europe. However, this situation changed with the turn of the century. A downturn in the Hungarian market, unsuccessful entrepreneurial activity by the Hungarian management that did not use the plant to full capacity, as well as a failed attempt to become the European centre of competence for switching production, finally led to the closure of production at Telefongyár in early 2003 . The subsidiary was downsized to approximately 250 employees and the role of Telefongyár downgraded to a marketing satellite. Recently the company was integrated as a communications division into Siemens Rt, the Hungarian regional company of Siemens.

\section{Cross-border management relationships}

We begin our journey inside the transnational social space of Siemens-Telefongyár by looking at the relevant cross-border management relationships and their characteristics. A particular focus is on the question of whether transnational communities emerge from these cross-border social relationships, and how their formation can be explained. Cross-border management relationships at Telefongyár were mainly centred around and characterised by the overall transition process and the adaptation of the Siemens production model in Hungary. There are four different but overlapping groups of managers in the 
centre of these developments, comprising the Hungarian top and middle managers, as well as Austrian top and middle managers (see Table 1).

Table 1. Core management groups in the transition process at venture level

\begin{tabular}{|l|l|l|}
\hline \multicolumn{1}{|c|}{ Expatriates } & \multicolumn{1}{c|}{ Local managers (Inpatriates) } \\
\hline $\begin{array}{l}\text { Top } \\
\text { Management }\end{array}$ & $\begin{array}{l}\text { Two managers from Siemens } \\
\text { Austria, for financial and technical } \\
\text { issues, respectively, assuming } \\
\text { overall responsibility for business. }\end{array}$ & $\begin{array}{l}\text { Six, later two, incumbent Telefongyár } \\
\text { managers; main function: securing market } \\
\text { access, interface to the Hungarian middle } \\
\text { management and personnel. }\end{array}$ \\
\hline $\begin{array}{l}\text { Middle } \\
\text { Management }\end{array}$ & $\begin{array}{l}\text { Approx. ten managers from Siemens } \\
\text { Austria, mainly transferring } \\
\text { knowledge to their Hungarian } \\
\text { counterparts in transfer tandems. }\end{array}$ & $\begin{array}{l}\text { Approx. ten incumbent Telefongyár } \\
\text { managers, mainly absorbing knowledge } \\
\text { from their Austrian counterparts in transfer } \\
\text { tandems. }\end{array}$ \\
\hline
\end{tabular}

Given the frequency of operational contacts, social relationships during the transition process were strong on both the horizontal and vertical axis. However, while vertical social relationships between Austrian top and middle managers, as well as between Hungarian top and middle mangers could rely on past experiences, horizontal and diagonal relationships were rather new, unfamiliar and to a certain extent burdened by conflicts of interest. Moreover, these relationships linked actors with different national backgrounds. The discussion below focuses on these challenging cross-border social relationships.

The social relationship among the Austrian and the Hungarian top management is perhaps best described as a 'Cinderella process': The Austrian top management tried to identify with whom they had to play in order to be successful in the Hungarian market and to whom they would hand over the overall business responsibility at the end of their mission. Even prior to the company acquisition, the Austrian top managers conducted an assessment of the top management team of Telefongyár. In the words of an Austrian expatriate manager, the aim of this process was to find out which members of the Telefongyár top management "pull together and which play their own game". According to this manager, those assessed as "playing their own game" were made redundant immediately after the acquisition had been completed. Indeed, four members of the incumbent Telefongyár top management team were fired in late 1991, among them the head of production, the head of logistics and the head of the organisation and information department. However, the remaining Hungarian top managers did not survive in their positions by agreeing to the new management ideas. In fact, they strongly opposed some decisions of the Austrian top management team, such as the cancellation of the overwhelming majority of already existing orders, mainly from Russia and the Arabic region. Moreover, they were openly critical of the overall strategy of Siemens in Central and Eastern Europe. According to one Hungarian top manager, “... Siemens was overstrained by the simultaneous opening of 15 or more markets in Central and Eastern Europe. Instead of following a strategy for the whole region they 
followed local strategies". The retained Hungarian top mangers could afford this frankness because they had unique personal contacts to the main Hungarian customer MATAV, contacts that were an indispensable prerequisite for success in the Hungarian market. While such early strategic conflicts were managed through the interaction of the Hungarian and Austrian top management teams at venture-level, strategic conflicts that occurred after the Austrian expatriates had left by the mid 1990s were managed on the intra-organisational level. However, irrespective of where these conflicts were located, their strategic nature and implication for the individual managers reputation generated high levels of discord and finally ended in top-down decisions from corporate headquarters. These processes and outcomes led to a certain level of disappointment among the Hungarian top management. For instance, in answer to questions as to why the Hungarian plant was closed in early 2003, one Hungarian top manager splenticly said: "It is better for me, if you address these questions to my colleagues in Munich" (i.e. the location of the headquarters).

Compared to the inherent strategic nature of the social relationship between the Austrian and the Hungarian top management teams, the relationship between the Austrian and Hungarian middle managers was mainly characterised by day-today operational problems associated with the transition and the adaptation of the Siemens production model. The level of conflict was generally lower here and conflicts were more often solved by sharing views or looking for joint solutions. Siemens applied a tandem system (Kessel/Dörr 1998) to manage transition at Telefongyár. In this system an Austrian expatriate and a Hungarian counterpart were jointly responsible for a certain function. Usually both the Austrian middle manager and his/her Hungarian counterpart shared an office and all important information and decisions. Almost all Austrian middle managers were recruited at the Siemens switching division in Vienna. The motivation to go to Hungary differed according to the age of the expatriate team members. Despite the fact that no binding promises were made by Siemens, the younger members were basically motivated by future career options. Generally these hopes were not fulfilled but, on the other hand, neither did their careers suffer upon return to Vienna. Most of the older members were intrinsically motivated. Either they wanted to escape their day-to-day routine, or they were strongly attracted by the possibility "of really making something happen" (or both). They achieved these expectations. Especially in the beginning, the expatriates were confronted with a much more demanding (and chaotic) situation than they had envisaged. As one expatriate put it: "During the first days I said to myself, what the hell motivated me to take over this job?" Solidarity within the team of Austrian middle managers helped in solving the initial problems encountered by the individual team members at the beginning of their engagement at Telefongyár.

The Hungarian counterparts in the tandems were designated after a detailed review of their capabilities by the Austrian top mangers. Initially the tandems 
were heavily impacted by the very different situations and expectations of their members. While many of the Austrian expatriates were especially attracted by the opportunity to "make something happen", i.e. to implement changes that they felt they could never do at home, their Hungarian counterparts were more or less anxious about the many changes to come. Above all, according to a representative from the labour force at Telefongyár, "job security was the major concern at that time". The anxiety of Hungarian middle managers was fuelled by many different sources, such as the general uncertainty of the transition phase, the loss of individual influence, the results of the former anti-capitalist propaganda, and the many examples of 'transition tragedies', such as politically motivated plant closures (to take capacities out of the market) or criminal privatisations. Thus at the outset, the social relationship in the tandems was characterised by a general lack of trust and mutual learning was scarce, as proposed by Balaton (2003). As one Austrian middle manager put it: "No matter how friendly their welcome to you and no matter how friendly you were to them and how seriously you took your counterpart, you were always considered a member of an occupying force." However, after six to twelve months a cooperative climate gradually developed within the tandems, fostered by day-today problem-solving. In a few cases the Hungarian counterpart was replaced by another local manager if the first choice was deemed to be unsatisfactory.

Collective identity-building processes took place within the tandems across frontiers. Shared interests with regard to the handling of the many day-to-day transition problems emerged quickly because both the Austrian and the Hungarian middle managers felt they were in a lock-in situation, albeit for different reasons. While Austrian middle managers could not afford to fail to overcome these problems because of the damage it would cause to their personal reputation, the Hungarian middle managers' professional career and social situation depended on their ability to prove they could resolve these problems successfully. Furthermore, especially the Austrian middle managers rather quickly discovered that overcoming the problems required at least some input from the Hungarian partners in the tandem. They needed local knowledge about legal provisions (e.g. in accounting, labour relations) as well as less codified knowledge, for instance on general business behaviour in Hungary (e.g. how to deal with customers, suppliers, the customs, the trade unions, local authorities). Moreover, speaking Hungarian was an important asset the Hungarian partners in the tandems held. As one Hungarian manager at Telefongyár stressed: "Just imagine an Austrian middle manager in Hungary heading a department and having to sign all these documents in Hungarian, which he doesn't understand."

The fact that collective identity processes took place and a transnational community of Austrian and Hungarian middle managers emerged around the notion of doing the "cumbersome and dirty work of transition", as one Hungarian middle manager put it, does not mean that there were no differences 
in the underlying social relationships. While in some tandems the partners just learned how to get along with each other, maintaining existing stereotypes and asymmetric power relations, others came to know and understand each other better. This involved, among other things, a general willingness to look for mutual solutions, as the following story, reported by both the Austrian and the Hungarian partner of a tandem, illustrates: as a relic of socialist times, the offices at Telefongyár were much larger than the Austrian middle managers were used to and were often furnished with a sofa. Having a sofa in the office that usually belonged privately to the manager was seen as a privilege and a status symbol. This was also the case here and the Austrian middle manager initially wanted the sofa to be taken out to provide more space for his desk. However, when the Hungarian counterpart proposed swapping the large sofa for a smaller one he agreed, even though he did not see the necessity for having a sofa in the office at all. The Hungarian middle manager, on the other hand, settled for a smaller status symbol. Particularly tandems with such a climate of mutual thoughtfulness, in which strong cross-border solidarity emerged, saw the partners developing close interpersonal relationships.

Unlike these two types of horizontal relationships (linking expatriates and local managers at different hierarchical levels), diagonal relationships between Hungarian top managers and Austrian middle managers, or vice versa, represent cross-border relationships without close day-to-day interaction. Two quite different kinds of dynamics were observed in the diagonal relationships, adding to the patchwork nature of social relationships in MNCs. While Austrian top managers and Hungarian middle managers had a rather distant relationship, very strong animosity was harboured by many Austrian middle managers against Hungarian top managers. In the eyes of quite a few Austrian middle managers the Hungarian top management was politically compromised. Austrian middle managers sometimes used Cold-War rhetoric, for example insulting a Hungarian top manager who had studied in Moscow by calling him a "dyed-in-the-wool communist" or a "red sock". It was difficult to discover the origin of this strong animosity on the part of the Austrian middle managers. However, it was evident that the self-image of some Austrian middle managers as 'white knights' arriving to 'save' Telefongyár was strongly disturbed by the strategic need to cooperate with members of the incumbent top management to achieve market access. This was further aggravated by the fact that the Hungarian top management exhibited high self-esteem and did not simply execute instructions but regularly discussed, opposed and tried to modify decisions proposed by the Austrian managers. Moreover, and probably most importantly, they challenged the necessity of (so many) Austrian middle mangers. As one Hungarian top manager put it: "In most cases it turned out that our former Telefongyár managers did and still do a good job". 


\section{Cross-border owner relationships}

Unlike cross-border management relationships that touch upon the strategic and operational dimension of the transition process at Telefongyár, cross-border owner relationships represent the different layers of governance to which Telefongyár was and is subject. At the intra-organisational level, particularly the relationship between the headquarters of the Siemens switching division in Bruchsal/Germany and the Austrian regional company impacted the transition process at Telefongyár.

Given the fact that local content requirements were typical in the switching industry, the headquarters of the Siemens switching division in Bruchsal/Germany had over time developed a standard procedure for building up a foreign switching subsidiary, which was carried out by a team of experts from the divisional headquarters. In the case of Telefongyár, however, this standard procedure was not employed, for two reasons. Firstly, market entry in Hungary, as a consequence of the tendering process, was achieved by acquisition rather than by a green-field investment, which was Siemens switching division's usual way of entering new foreign markets. Secondly, a shortage of headquarters experts existed, resulting from the sudden fall of the Wall, instantly creating business opportunities in many different Central and Eastern European countries. Why the Austrian regional company was assigned the task of building up the switching business at Telefongyár remains unclear. Various historical and more task-related answers were given in the interviews, such as: "Austrians and Hungarians have a long common tradition ("K\&K" monarchy), leading to a great cultural proximity", "much of the pre-1989 business of Siemens was transacted by Siemens due to the different political status of Austria" or "Budapest is only $200 \mathrm{~km}$ away from Vienna". Moreover, it was stressed that the small-scale production at Siemens Austria resembled the production to be built up at Telefongyár much more closely than did the largescale production at the divisional headquarters in Bruchsal, thus guaranteeing a better structural fit between transfer source and transfer target. However, quite a few interview partners also saw the acquisition of Telefongyár by Siemens Austria as an expression of the Austrian regional company's general policy of increasing its autonomy in the network of Siemens companies. In the words of one of the interviewees: "Siemens Austria, being one of the largest and most profitable regional companies throughout Siemens, is always agitating for stronger decentralisation." Especially interview partners with a divisional background viewed the strong and growing position of the Austrian regional company as a major, constant source of conflict within the matrix-organisation of Siemens.

With the Austrian regional company adopting ownership shares and the responsibility for managing the day-to-day transition process, a twofold management structure was not only installed in the ownership structure (as 
described above) but also in the daily management. While expatriates from Siemens Austria were managing the transition process at Telefongyár, the headquarters of the German telecom division (belonging to Siemens AG, Germany) remained responsible for the strategic aspects of marketing and sales at Telefongyár (i.e. all product specifications and basic technologies came from Siemens Germany). This twofold governance structure rather quickly unleashed conflicts in the relationship between the Austrian regional company and the divisional headquarters in Germany, adding another facet to the mosaic of social relationships in and around the Siemens-Telefongyár venture. The Austrian efforts with regard to the transition of Telefongyár were considered more or less successful, but critics at the divisional level maintained throughout the whole transition process that the overall costs of the transition process undertaken by the Austrian expatriates by far exceeded the costs for the normal Siemens standard operating procedure for developing a switching company abroad. In addition, the more than respectable profits Telefongyár achieved in the years immediately after the acquisition led to conflicts between Siemens Austria and the parent company Siemens AG in Germany as to where these should flow. The divisional headquarters welcomed the final decision by the parent company Siemens AG to adopt the shares of Siemens Austria in Telefongyár in the mid1990s and thus to directly channel the profits to the parent company, but the managers of the Austrian regional company, as well as the expatriate Austrian top and middle managers, felt this decision negated their work and their achievements.

A somewhat more distant owner relationship which nevertheless had and continues to have an impact on the Telefongyár venture is the change in the overall owner-management relationship at Siemens. For many decades Siemens was considered the prototype of a large German industrial company: i.e. a somewhat bureaucratic, technology-driven, long-term oriented company, strongly rooted in its German home environment with trust-based relations both towards labour and capital (Lane 2001). However the 1990s have seen some changes at Siemens in this respect, best described by the buzzword 'financialisation'. 'Financialisation' describes the gradual change from management control to stock market control (Lazonick/O'Sullivan 2000), which many companies undertook during the 1990s. One of the first steps representing this change at Siemens was the so-called 'Ten Point Program', issued in 1998 in the wake of the listing of Siemens on the New York Stock Exchange. The 'Ten Point Program' aimed at restructuring the portfolio, stabilising troubled business segments, and introducing binding yardsticks for measuring performance throughout the entire group. Two years later a program called 'Operation 2003' supplemented the 'Ten Point Program' by setting binding profit goals for each division to be reached in the 2003 fiscal year. The deadline for reaching these goals was extended to 2007 for the troubled information and communication business area, with restructuring efforts gaining a strong momentum from 2003 
on. The closure of the switching plant at Telefongyár in 2003 was among the first such restructuring efforts. The Hungarian market collapsed in 2001, the decision to close down the plant at Telefongyár was taken in 2002, and the closure was executed in 2003 . With this decision, which was mainly advocated at divisional level, a good deal of the efforts that the Austrian expatriates and the Hungarian management had devoted to the transformation of Telefongyár was obliterated. Prior to this decision, the Hungarian top management unsuccessfully tried to acquire new additional orders from other Siemens divisions as well as from outside customers. ${ }^{1}$ Moreover, a proposal by Hungarian top management to turn Telefongyár into the European centre for switching production and to relocate all European switching production to Hungary was not supported by headquarters.

\section{Conclusion}

The insights gained in this study into the social relationships in and around the Siemens-Telefongyár venture in the first 15 years of transition indicate that the transnational social space of an MNC is a complex amalgam of intertwined cross-border social relationships that have their own ends, trajectories and characteristics. Two generic types of social relationship interacted with one another: management relationships and owner relationships. A certain hierarchical order of social relationships is particularly evident in this case. The owner relationships strongly had a strong priority over and negated management relationships. Moreover, within management relationships, the influence of headquarters by and large dominated over the local subsidiary managers' concerns, adding to the very hierarchical setting of cross-border social relationships. This seems to be typical for East-West ventures (Geppert/Clark 2003), and perhaps also for asymmetrical ventures in general, but it is not typical for all MNCs, or more precisely for all headquarters-subsidiary constellations in an MNC. A recent case study by Kristensen and Zeitlin (2005) found a far less asymmetrical distribution of power between headquarters and subsidiaries. In their case, subsidiaries not only pursued their own agendas, as in our case, but also succeeded in making deals with the headquarters that at least partly reflected their own interests, adding to a much more dialectical picture of the MNC than our case study would suggest. Thus, more systematic comparative research is needed to generate a better understanding of the impact of distinct headquarters-subsidiary constellations as well as of different governance styles applied by headquarters (Clark/Geppert 2006).

1 Physically, switching systems consist of specifically fitted printed circuit boards. Printed circuit boards are used in many electrical appliances. 
A second conclusion, which emerges from the longitudinal scope of the Siemens Telefongyár case study, is that environments and strategic situations, as well as the interpretation of these, change over time. These changes influence the various cross-border social relationships either by altering their nature (if they still exist) or changing their ex-post evaluation. Thus, the many and costly efforts of Siemens to develop a state-of-the-art switching factory at Telefongyár were more or less destroyed after only ten years, when the Hungarian switching market collapsed, and the headquarters decided to abandon the production in Hungary rather than making more use of it as a European centre for the production of switching systems. With these decisions taken, the headquarters erased the different cross-border social relationships at the management level and by the same token the many individual efforts and emotional commitments made to these relationships. This finding demonstrates the transience of crossborder social relationships and social orders in MNCs and has two theoretical implications. First, frameworks for analysing the shape cross-border social relationships in MNCs take (e.g. Morgan 2001b) or more generally the social orders emerging in MNCs (e.g. Clark/Geppert 2006) need to be extended to more successfully incorporate change and trajectories of change. Second, the case study reveals that there is a systemic trade-off between strategic decisions that negatively affect cross-border social relationships and overall social integration measures in MNCs. Closing down the switching plant at Telefongyár, which had been built up just a few years earlier, created much frustration. Whether the commitment of these people can be regained by supporting the managers' understanding of the overall corporate vision as proposed by Bartlett and Ghoshal (1989) is questionable and needs more empirical research. The Siemens' vision statement (as is the case for vision statements of MNCs in general) is highly dialectical (not to say contradictory) and open to interpretation. For example, it demands "creating the greatest possible value for our shareholders" while at the same time "upholding an exacting set of values - including humanity, equal opportunity and strict ethical standards" (Siemens 2005:5).

A third conclusion of the case study also leads to some ideas about the different shapes cross-border social relationships might take. According to Morgan (2001a, b), cross-border social relationships might take the form of transnational communities, i.e. communities of individuals in an MNC that exhibit a unique cross-national organisational identity despite the fact that their national and organisational origin is diverse. The case study suggests that transnational communities only rarely emerge in MNCs, and when they do, their existence is temporary and precarious, rather than a long-lasting and stable. In this case study, only one out of four management relationships and none of the two owner relationships studied showed traits of an emerging transnational community. Moreover, the transnational community composed of Austrian and Hungarian middle managers only existed for a short period of time. Almost all Austrian 
expatriate middle managers were repatriated after three years. One important question here is whether this result is generally applicable. Little has been said so far about the conditions that lead to the emergence of transnational communities. According to Morgan (2001b, p. 118) "prolonged structured interaction" that allows for the mutual recognition of common interests is necessary. However, this case study shows that not only the frequency and length of interaction, but also the strategic load, make a difference. Here, the underlying mechanisms and interrelationships need to be explored in more detail.

\section{Acknowledgements}

I would like to thank Ariane Berthoin Antal, Lazlo Neumann, Sigrid Quack, and two anonymous reviewers for their very helpful comments on earlier versions of this paper.

\section{References}

Aharoni, Y. (1966): The Foreign investment decision process. Boston: Harvard University Press.

Balaton, K. (2003): Changing patterns of leadership during the transformation period in Hungary, in: Journal for East European Management Studies, 8, 4, 335-345.

Balaton, K. (2004): Researching organizations in Hungary: practical experience and Methodological Reflections, in: Clark, E. /Michailova, S. (eds.): Fieldwork in transforming societies. Understanding methodology from experience. Houndmills: PalgraveMacmillan, 97-113.

Baliga, B.R./Jaeger, A.M. (1984): Multinational corporations: Control systems and delegation issues, in: Journal of International Business Studies, 15, 2, 25-40.

Bartlett, C.A./Ghoshal, S. (1989): Managing across borders. The transnational solution. Boston MA: Harvard Business School Press.

Birkinshaw, J. (1996): How multinational subsidiary mandates are gained and lost, in: Journal of International Business Studies, 27, 3, S.467-495.

Birkinshaw, J. (2000): Entrepreneurship in the global firm. London/Thousand Oaks/New Delhi: Sage.

Birkenshaw, J. (2001): Strategy and management in MNE subsidiaries, in: Rugman, A./ Brewer T.L. (eds.): The Oxford handbook of international business. Oxford/New York: Oxford University Press, 380-401.

Birkinshaw, J./Ridderstrale, J. (1999): Fighting the corporate immune system: A process study of subsidiary initiatives in multinational corporations, in: International Business Review, 8, 149-180.

Clark, E./Geppert, M. (2006): Socio-political processes in international management in postsocialist contexts: Knowledge, learning and transnational institution building, in: Journal of International Management, 12, 3, 340-357. 
Clark, E./Lang, R./Balaton, K. (2001): Making the transition: Managers and management in transforming and reforming economies, in: International Studies of Management \& Organization, 31, 2, 3-7.

Das Parlament (1990): Langjährige Beziehungen Deutschland Ungarn, August, 17, 1990.

Dörrenbächer, C./Geppert, M. (2006): Micro-politics and conflicts in multinational corporations: Current debates, re-framing, and contributions of this special issue, Journal of International Management, 12, 3, 251-265.

Edwards, T./Rees, C./Coller, X. (1999): Structure, politics and the diffusion of employment practices in multinationals, in: European Journal of Industrial Relations, 5, 3, 286-306.

Eisenhardt, K., (1989): Building theories from case study research, in: Academy of Management Review, 14, 4 , 532-550.

Forsgren, M./ Holm, U./Johanson. J. (2005): Managing the embedded multinational: A business network view. Cheltenham: Edward Elgar.

Franko, L.G. (1976): The European multinationals. London:Harper \& Row Publishers.

Ganter, H.D./Walgenbach, P. (2002): Middle managers: Differences between Britain and Germany, in: Geppert, M./Matten, D./William, K. (eds.): Challenges for European management in a global context - Experiences from Britain and Germany. Houndsmills: Palgrave MacMillan., 165-188.

Gates, S. / Egelhoff, W. (1986): Centralization in headquarters-subsidiary relations, in: Journal of International Business Studies, 17, 2, 71-92.

Geppert, M./Clark, E. (2003): Knowledge and learning in transnational ventures: An actorcentred approach, in: Management Decision, 41, 5, 433-442.

Harvey, M.G./Novicevic, M.M./Speier, C. (1999): Inpatriate managers: How to increase the probability of success, in: Human Resource Management Review, 9, 1, 151-181.

Harzing, A.W. (1999): Managing the multinationals. An international study of control mechanisms. Cheltenham/Northampton: Edward Elgar.

Hedlund, G. (1986): The Hypermodern MNC - A heterarchy? in: Human Resource Management, 25, 1, 9-35.

Houman-Andersen, P./Skaates, M.A. (2004): Ensuring Validity in Qualitative International Business Research, in: Marschan-Piekkari, R. /Welch C. (eds.): Handbook of qualitative research methods for international business. Cheltenham/Northampton: Edward Elgar, 464-485.

Huy, Q.N. (2001): In Praise of Middle Managers, in: Harvard Business Review, September, $2-79$.

Inkpen, A.C./Beamish. P.W. (1997): Knowledge, bargaining power, and the instability of international joint ventures, in: Academy of Management Review, 22, 1, 177-202.

Johnston, S. (2005): Headquarters and subsidiaries in multinational corporations. Strategies, tasks and coordination. Houndsmills Basingstoke: Palgrave Macmillan.

Kessel, T./Dörr, G. (1998): Management zwischen Transformation und Restrukturierung. Zwei Transfermodelle von Ost-West-Kooperationen, in: Barmeyer, C./Bolten, J. (eds): Interkulturelle Personalorganisation. Berlin: Verlag Wissenschaft und Praxis, 33-48. 
Kristensen P.H /Zeitlin, J. (2005): Local players in global games. The strategic constitution of a multinational corporation. Oxford: Oxford University Press.

Lane, C. (2001): The Emergence of German transnational companies: A theoretical analysis and empirical study of the globalization process, in: Morgan, G./Kristensen, P.H./ Whitley, R. (eds): The multinational firm. Organizing across institutional and national divides. Oxford: Oxford University Press,69-96.

Lazonick, W./O'Sullivan, M. (2000): Maximizing shareholder value: A new ideology for corporate governance, in: Economy and Society, 29, 1, 13-35.

Michailova, S. (2004): Contextualizing fieldwork: Reflections on conducting research in Eastern Europe, in: Marschan-Piekkari, R. /Welch C. (eds.): Handbook of qualitative research methods for international business. Cheltenham/Northampton: Edward Elgar, 365-383.

Mirow, M. (1996): Kooperations- und Akquisitionsstrategie in Osteuropa am Beispiel der Elektroindustrie, in: Zeitschrift für betriebswirtschaftliche Forschung, 10, 934-946.

Morgan, G. (2001a): The multinational firm. Organizing across institutional and national divides. Morgan, G./Kristensen, P.H./Whitley, R. (eds): The multinational firm. Organizing across institutional and national divides. Oxford: Oxford University Press,1-24.

Morgan, G. (2001b): Transnational communities and business systems, in: Global Networks, $1,2,113-130$.

Müller, J. (1998): Restructuring of the telecommunications sector in the West and the East and the role of science and technology. Final Summary Paper, September 1998. Berlin: Mimeo.

Neumann, L./Tóth, A./Berkó, L. (1993): Management/labour relations at Hungarian affiliates of multinational enterprises. OECD - Ministry of Labour, Budapest: Mimeo.

Nohria, N./Ghoshal, S. (1997): The differentiated network: Organizing multinational corporations for value creation. San Francisco: Jossey-Bass.

Petit, T.A. (1975): Fundamentals of management coordination: supervisors, middle managers, and executives. New York:Wiley.

Pries, L. (2001): The Approach of transnational social spaces. Responding to new configurations of the social and the spatial, in: Pries, L. (ed.): New transnational social spaces. International migration and transnational companies in the early twenty-first century. London: New York: Routledge, 3-33.

Schatzki. T. (2005): The sites of the organizations, in: Organization studies, 25, 3, 465-484.

Shenkar, O./Yan, A. (2002): Failure as a consequence of partner politics: Learning from the life and death of an international cooperative venture, in: Human Relations, 55, 5, 565-601.

Siemens (2005): Annual Report 2005. Munich: Mimeo.

Soulsby, A. (2004): Who is observing whom? Fieldwork roles and ambiguities in organizational case study research, in: Clark, E./Michailova, S. (eds.): Fieldwork in transforming societies. Understanding methodology from experience. Houndmills: PalgraveMacmillan, 39-56. 
Steger, T. (2004): Identities, roles and qualitative research in Central and Eastern Europe, in: Clark, E./Michailova, S. (eds.): Fieldwork in transforming societies. Understanding methodology from experience. Houndmills: PalgraveMacmillan, 19-38.

Stewart, R. (1976): Contrasts in management - A study of different types of managers' jobs: Their demands and choices. Maidenhead/Berkshire: McGraw-Hill.

Stopford, J.M./Wells, L.T. (1972): Managing the multinational enterprise. Organization of the firm and ownership of subsidiaries. New York: Basic Books.

Taggart, J.H. (1998): Strategy shifts in MNC subsidiaries, in: Strategic Management Journal, $19,663-681$.

The Economist (2000): The World's View of Multinationals. January 29, 2000, 19-20.

van den Bulcke, D. (1984): Decision making in multinational enterprises and the information and consultation of employees: The proposed Vredeling Directive of the EC Commission, in: International Studies of Management and Organization, 14, 1, 26-60.

Weick, K.E. (1995): Sensemaking in organizations. Thousand Oaks: Sage.

Welch, C./Marschan-Piekkari, R./Penttinen, H./Tahvanainen, M. (2002): Corporate Elites as Informants in Qualitative International Business Research, in: International Business Review, 11, 611-628.

White, R.E./ Poynter, T.A. (1984): Strategies for foreign-owned subsidiaries in Canada, in: Business Quarterly, 49, 2, 59-69.

Yin, R.K. (2003): Case study research. Design and methods. 3th edition. Thousand Oaks, CA: Sage. 